\title{
O mal-estar na representação: autoidentidade, esquizofrenia e a teatralidade do mundo social*
}

Recebido:

Aprovado:
Gabriel Peters**

Resumo: O artigo é parte de um programa de pesquisa em "heurística da insanidade", o qual explora o poder analítico de ferramentas sociológicas na compreensão da esquizofrenia, assim como a relevância de investigações da experiência esquizofrênica para a teoria social, sobretudo no que toca às concepções de agência, experiência e subjetividade que nela vigoram. No seio deste programa mais geral, o trabalho revisita perspectivas dramatúrgicas sobre a relação entre self e sociedade, entrecruzando tais perspectivas com a literatura psiquiátrica acerca de perturbações "esquizoides" no relacionamento do sujeito com o mundo e consigo próprio. Se as visões dramatúrgicas da subjetividade criticam, no plano teórico, o pressuposto de senso comum de que haveria um "eu" estável e nitidamente distinto das máscaras teatrais que ele "veste" na vida social cotidiana, algumas perturbações da autoidentidade ou senso de si na esquizofrenia são concretizações existenciais, efetivamente vividas, dessa dissolução do "eu" em um feixe de papéis ou identidades sociais.

Palavras-chave: Autoidentidade. Papel social. Fenomenologia. Esquizofrenia. Sociologia dramatúrgica.

\section{Representation and its discontents: self-identity, schizophrenia and the theatricality of the social world}

Abstract: The article is part of a research program on the "heuristics of insanity", which explores the analytical power of sociological tools for the understanding of schizophrenia, as well as the relevance of investigations of schizophrenic experience for social theory, especially concerning its current conceptions of agency, experience and subjectivity. Within this more general program, the paper revisits dramaturgical perspectives on the relation between self and society, intercrossing these perspectives with the psychiatric literature on "schizoid" disturbances of the subject's relationship with the world and with him/herself. If dramaturgical views of subjectivity criticize, at a theoretical level, the common-sense presupposition according to which there is a "self" that is both stable and clearly distinct from the theatrical masks it "wears" in everyday social life, some disturbances of self-identity or the sense of one's self in schizophrenia are experientially lived realizations of this dissolution of one's self into a stream of social roles or identities.

Keywords: Self-identity. Social role. Phenomenology. Schizophrenia. Dramaturgical sociology.

\author{
* Uma primeira \\ versão do presente \\ artigo foi discutida \\ com colegas do \\ Grupo de Estudos \\ em Teoria Social \\ e Subjetividades \\ (GETSS) no Programa \\ de Pós-Graduação \\ em Sociologia da \\ Universidade Federal \\ de Pernambuco \\ (PPGS-UFPE). \\ Agradeço a Cynthia \\ Hamlin, Filipe \\ Campello, Luciana \\ Mendonça, Mariana \\ Pimentel, Suzy Luna \\ e Thiago Panica por \\ suas considerações \\ críticas acerca \\ daquela versão. \\ Agradecimentos \\ também são devidos \\ a Artur Perrusi, Diogo \\ Corrêa, Frédéric \\ Vandenberghe, \\ Lidiane Rodrigues, \\ Luís de Gusmão \\ e Sue lamamoto \\ por conversas que \\ lançaram luz, para \\ mim pelo menos, \\ sobre diversos dos \\ temas explorados \\ neste trabalho. \\ Finalmente, \\ sou grato a dois \\ pareceristas \\ anônimos de \\ Sociedade e Estado \\ por seus comentários \\ e sugestões a \\ respeito do artigo \\ tal qual o submeti \\ originalmente à
}


revista. Quaisquer inadequações no seu feitio final continuam sendo, é desnecessário dizer (mas direi mesmo assim), de minha inteira responsabilidade.

** Gabriel Peters é professor do Departamento de Sociologia da Universidade Federal de Pernambuco, Recife, Pernambuco, Brasil.

Orcid: 00000002-0595-2663 <gabrielpeters@ hotmail.com>.

1. Para dar apenas um exemplo, o acento giddensiano sobre a importância da rotina para uma experiência ontologicamente segura do mundo revelou-se relevante na compreensão etnográfica de vivências cotidianas em cenários urbanos marcados pela violência, como as favelas cariocas (Silva \& Leite, 2008: 74).
Introdução:

\section{teoria da ação e heurística da insanidade}

$\bigwedge$

despeito do que pode sugerir a referência à esquizofrenia no seu título, o presente artigo não é um texto de psicologia clínica, mas uma reflexão sistemática em teoria social. Como sublinharam diversos autores (e.g., Alexander, 1987: 13), nenhuma abordagem teórica nas ciências sociais pode escapar à formulação - implícita ou explícita - de concepções acerca da natureza da ação humana e, por extensão, da subjetividade do agente. Em outras palavras, qualquer caracterização analítica das estruturas e dos processos constitutivos do mundo social pressupõe uma "teoria psicológica" no sentido mais básico da expressão, isto é, uma teoria dos motores subjetivos da conduta humana. A relação entre a teoria social como empreitada interdisciplinar, de um lado, e quaisquer outras disciplinas que lidem com os propulsores subjetivos da ação humana, de outro, é de mão dupla. Se contribuições oriundas da psicologia, da sociologia, da antropologia e tutti quanti alimentam as reflexões mais gerais da teoria social, as próprias abordagens à subjetividade humana desenvolvidas nesse âmbito mais abstrato podem alimentar pesquisas empíricas em disciplinas específicas. Uma ilustração da primeira via heurística citada - que vai de ciências humanas particulares à reflexão socioteórica - está no uso que a teoria da estruturação de Anthony Giddens (2003: 71-75) faz dos trabalhos do psicanalista Bruno Betelheim sobre as transformações psicológicas sofridas por prisioneiros dos campos de concentração nazistas. Se Giddens recorreu à psicologia betelheimiana para formular seu conceito de "segurança ontológica" em um âmbito mais geral, a noção elaborada por Giddens mostrou-se útil, por sua feita, a pesquisas empíricas em disciplinas singulares ${ }^{1}$.

Pretendo defender, neste texto, a tese de que uma relação heurística de mão dupla também pode ser estabelecida entre perspectivas mais abrangentes da teoria social, de um lado, e o estudo interdisciplinar de "doenças mentais" ou "psicopatologias", de outro. Por um lado, a teoria social fornece ferramentas analíticas úteis à compreensão das vivências e comportamentos psicopatológicos, muitas vezes capturando seus aspectos ambivalentes (por exemplo, suas complexas misturas de lucidez e cegueira, "competência" e "incompetência", "excesso" e "déficit") de modos que escapam tanto ao simplismo de certa obtusidade psiquiátrica quanto à romantização irresponsável a que a loucura é submetida na pena de alguns críticos da psiquiatria. Ao mesmo tempo, o exame das psicopatologias como formas de ação e experiência ilumina criticamente as concepções mais gerais de "agente humano" que vigoram na teoria social. Nesse sentido, a discussão que vai adiante é parte de um programa de pesquisa mais amplo, o qual procura não apenas mobilizar as ferramentas analíticas da teoria social para compreender a loucura, mas também, de 
modo mais ousado, partir do estudo da loucura para repensar criticamente a teoria social, sobretudo no que toca às noções de agência, experiência e subjetividade que nela vigoram.

Em termos metodológicos, esse procedimento poderia ser definido como uma "heurística da insanidade" ou, de maneira mais provocativa, uma "epistemologia insana". Tal modo de análise confere ao exame de vivências insanas na teoria social um papel epistêmico similar ao do esquadrinho da variedade de formas de ação e experiência humana em disciplinas como a história e a antropologia cultural². Sem que seja preciso descambar para uma visão rósea e idealizada da loucura, a qual escamoteia os extraordinários sofrimentos e dificuldades por ela provocados, pode-se defender que a investigação de experiências insanas também amplia nosso senso da variedade de maneiras do "ser-no-mundo" humano. Em compasso com os defensores de uma "sensibilidade histórica" (Giddens, 1986: 13-14) e de uma "sensibilidade etnológica" (Kurasawa, 2004) como ingredientes heurísticos indispensáveis à imaginação sociocientífica, poder-se-ia advogar, no mesmo espírito, que a teoria social faria bem em se deixar imbuir de uma "sensibilidade psicopatológica". No presente contexto, o termo designa uma sensibilidade intelectual atenta ao que os estudos sobre a loucura nos revelam acerca da multiplicidade de formas de ação e experiência humana - sejam elas mais ou menos (in)felizes, mais ou menos (a)normais, mais ou menos (dis)funcionais, segundo nossas concepções ético-políticas.

\section{Esquizofrenia e (in)segurança ontológica}

A ideia de "segurança ontológica" já serve como um excelente ponto de interface entre a teoria social e o estudo interdisciplinar da psicopatologia. Como é sabido, Giddens recorreu a este conceito tanto em sua teoria da estruturação como em sua sociologia histórica da modernidade tardia. Em sua ontologia da vida social (Giddens, 2003: 59-75), o anseio humano por segurança ontológica desponta como um dos fatores responsáveis pela tendência à rotinização das práticas societárias. Influenciada por visões radicalmente processuais do mundo social - tais como a etnometodologia de Harold Garfinkel -, a teoria da estruturação se viu diante da questão: se a ordem social não é um dado, mas um produto contínuo e contingente de práticas históricas, por que os agentes investem tanto, afinal, em sua manutenção? Sem reduzir a explicação da ordem societária aos anseios psíquicos do agente humano, Giddens (2003: 444) sublinhou que tais anseios são parte sine qua non da resposta à pergunta. Um dos motivos pelos quais os agentes humanos investem continuamente na constituição e reconstituição da ordem social é precisamente

2. Na medida em que tais disciplinas tornam patente a multiplicidade de modos de agir, pensar e sentir dos seres humanos nas esferas mais diversas (da sexualidade à economia, da culinária à religiosidade), elas funcionam como antídoto à tendência espontânea da/o cientista social a considerar os atributos de seus próprios cenários sociais como naturais ou universais (p.ex., a sexualidade monogâmica ou a religiosidade monoteísta). 
3. Em seu retrato posterior dos traços estruturais da modernidade tardia (Giddens, 2001), o teórico britânico explora, em particular, como a sede de segurança ontológica passa pela "confiança" ou "fé" que depositamos ou somos obrigados a depositar em "sistemas peritos" (Giddens, 2001: 25) cujos mecanismos internos desconhecemos, tais como o planejamento urbano, a distribuição de energia elétrica ou a aviação civil.

4. Em outras palavras, o "mundo real" não é primordialmente vivenciado como noção abstrata à qual chegamos indutivamente, quando pensamos no domínio em que aquelas entidades existem, mas é o envoltório experiencial mesmo no qual as percebemos desde o início. De resto, é somente contra este pano de fundo tácito, pois tido como óbvio, que eventos particulares podem aparecer à nossa consciência como enigmáticos. um anelo existencial por segurança ontológica, isto é, por uma experiência do mundo e de si como dotados de sentido, organização, inteligibilidade, previsibilidade, confiabilidade etc. ${ }^{3}$. O que poucos sabem é que, antes de ser popularizado por Giddens, o conceito de segurança ontológica já havia sido mobilizado em um estudo fenomenológico-existencial da esquizofrenia de autoria de Ronald Laing (1990: 39), o qual retratava tal condição psíquica precisamente como uma experiência de "insegurança ontológica" radical.

Ao cunhar a expressão "esquizofrenia" por volta de 1911, o psiquiatra suíço Eugen Bleuler (1969) articulou radicais gregos que se referem, respectivamente, à "cisão" e à "mente". Desde o início, portanto, essa categoria diagnóstica já aludia a cisões ou a fissuras na relação vivida da subjetividade consigo mesma, com o mundo material e/ou com o mundo das outras pessoas. Eis também as três dimensões centrais na descrição de Laing (1990: 39) quanto à segurança ontológica e, por extensão, quanto ao seu colapso na esquizofrenia. Em primeiro lugar, diversos quadros de esquizofrenia se caracterizam por uma ruptura do senso de entrelaçamento entre a própria subjetividade e o mundo, uma quebra na experiência de imersão pré-reflexiva em um mundo tomado como indubitavelmente existente, tão bem descrita na fenomenologia existencial por autores como Heidegger e Merleau-Ponty. O mundo vivido não mais aparece, então, como o horizonte familiar e imediatamente inteligível da própria conduta, mas é transfigurado, nas palavras do pintor-escritor Giorgio de Chirico, em um "vasto museu de estranheza" (apud Sass, 1992: 43). Por contraste, uma relação ontologicamente segura com o mundo não toma sua existência como problemática, mas como absolutamente autoevidente. O mesmo vale para os atributos de substancialidade, continuidade e compreensibilidade das entidades que o compõem ${ }^{4}$.

Uma experiência ontologicamente segura depende, portanto, da "confiança" de que "os mundos natural e social são o que parecem ser" (Giddens, 2003: 444), confiança que carrega um elemento de aposta ou, nos termos de Merleau-Ponty (1971: 15), uma "fé" de que "vemos as coisas mesmas", de que "o mundo é aquilo que vemos". Na medida em que a atribuição de inteligibilidade às entidades do mundo ocorre no tempo, o pressuposto da "confiabilidade (reliability) dos processos naturais" (Laing, 1990: 39) inculca em nós um senso de relativa previsibilidade sem o qual nossa ansiedade sairia facilmente de controle. As expectativas quanto ao desenrolar previsível dos eventos do mundo não são puras representações cognitivas; ao contrário, quanto mais bem fundadas na experiência reiterada, mais elas podem ser abandonadas a um domínio tácito - por exemplo, a expectativa de que o cobrador entenderá nosso gesto de estender a ele o dinheiro da passagem ou a confiança visceral, como que depositada no corpo, de que um tiroteio é uma 
ocorrência improvável em uma biblioteca repleta de estudantes. Os exemplos já indicam que os atributos implicados na pressuposição da confiabilidade das coisas se estendem, mutatis mutandis, para o universo das demais pessoas: acreditamos que elas existem "substancialmente", isto é, fora e independentemente das representações que fazemos delas; confiamos na relativa compreensibilidade de sua conduta para todos os propósitos práticos; e, finalmente, mobilizamos expectativas quanto aos comportamentos prováveis que delas podemos esperar, o que serve para mitigar um sem número de incertezas angustiantes quanto ao que elas farão.

Como os exemplos permitem apreender, a riqueza heurística do conceito de (in) segurança ontológica advém, entre outras coisas, do fato de que ele captura vivências inseparavelmente cognitivas e afetivas, intelectuais e viscerais. Se a crença na realidade do mundo circundante não consiste em uma pura representação cognitiva, mas em uma vivência existencial global e difusa, o mesmo se aplicaria às experiências esquizofrênicas de perturbação ou, mais radicalmente, de dissolução desse senso de realidade.

Laing ilustra inteligentemente essa ideia ao comparar o ceticismo como puro exercício intelectual de filósofos, de um lado, ao "ceticismo" como inescapável experiência vivida entre certos pacientes de esquizofrenia, de outro. Uma filósofa cética pode sustentar, em suas aulas e em seus artigos, que ela não possui garantia racional absoluta de que o mundo que ela percebe pelos seus sentidos exista efetivamente fora de sua mente. Já que todas as "provas" da existência do mundo externo chegam a ela através de sua subjetividade, tais "provas" seriam todas logicamente compatíveis com a possibilidade de que não exista nada além dos conteúdos de sua experiência subjetiva. A filósofa também poderia afirmar que não é possível asseverar, com certeza apodítica, que as pessoas com quem ela interage são realmente dotadas de consciência e vida interior. Já que tudo que ela pode apreender dos outros são condutas corpóreas exteriormente observáveis, não existiria certeza absoluta - continua ela - de que esses corpos não sejam meros autômatos sem subjetividade. Ao transmitir esses argumentos céticos para seus estudantes, no entanto, a filósofa não abandona nem por um instante a crença visceral, vivida na carne, de que as paredes da sala de aula existem independentemente de sua subjetividade. Mesmo ao afirmar aos seus estudantes que ela não tem prova absoluta de que eles não sejam simples projeções de sua mente, seu argumento filosófico não chega a corroer sua certeza existencial de que aqueles estudantes diante dela são, sim, criaturas conscientes em vez de simples autômatos. Ao descrever vivências de radical insegurança ontológica, Laing nos convida então a um exercício imaginativo: como seria um indivíduo que levasse visceralmente a sério, em sua vida cotidiana e no trato com os outros, as dúvidas radicais que os filósofos se acostumaram a entreter 
em seus gabinetes? O que acontece quando a incerteza acerca da existência do próprio corpo, das coisas materiais ou das outras mentes não é mais um exercício intelectual, mas uma experiência vivida?

Nas perturbações da segurança ontológica, o elemento "esquizo" ou de ruptura pode incidir não apenas na relação da subjetividade com o mundo, mas também na relação da subjetividade consigo mesma. Na perspicaz conceituação de Laing, um senso de segurança ontológica comporta uma noção firme da própria existência como distinta daquela de outras pessoas, a vivência da continuidade de si mesmo ao longo do tempo e a experiência tácita - uma vez que considerada como absolutamente autoevidente - de que os pensamentos, as imagens e os sentimentos que emergem no espaço interior de minha subjetividade são "meus" (Jaspers, 1979b: 701). Cada um desses aspectos da experiência normal de si pode ser severamente perturbado ou mesmo entrar em colapso em casos de esquizofrenia. A contraparte do senso seguro de que a própria subjetividade é distinta de outras evidencia-se no terror, vivenciado por certos pacientes, de ter a própria existência subjetiva aniquilada, invadida ou "engolfada" (Laing, 1990: 43) pelo outro. Louis Sass e Joseph Parnas narram o caso de um jovem que

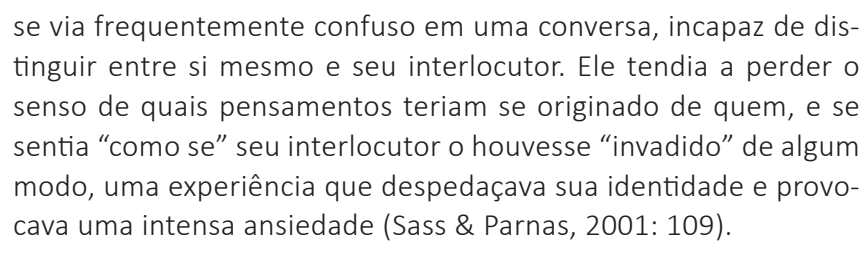

5. Como veremos em maiores detalhes, a literatura sobre a esquizofrenia também está repleta de cenários de radical desconexão vivida com o próprio corpo. Sass e Parnas (2001: 109) relatam, por exemplo, a história de um indivíduo tão inseguro quanto à própria existência corpórea que evitava olhar para o seu reflexo no espelho, já que isto gerava nele uma angustiada dúvida quanto a qual dos lados do vidro ele realmente estava.
Ainda no que toca a perturbações do senso de autoidentidade ou autopropriedade - "minhidade" (mineness) - da experiência subjetiva, um dos sintomas mais desconcertantes da esquizofrenia, em suas fases ou modalidades psicóticas, é o da "inserção de pensamento" (thought insertion). Nesses casos, os pacientes reconhecem que certos eventos (pensamentos, imagens, sensações, emoções etc.) ocorrem em sua subjetividade, mas não os reconhecem como "seus", e sim como experiências inseridas em sua mente por outras entidades, como, por exemplo, um aparelho eletrônico (Tausk, 1992) ou uma pessoa. Uma paciente sustentava, por exemplo, que sua mente era invadida pelos pensamentos de um famoso apresentador de rádio e TV do Reino Unido:

\footnotetext{
Eu olho pela janela e penso que o jardim parece bonito e a grama parece bacana, mas os pensamentos de Eamonn Andrews [o apresentador] vêm à minha mente... [...] Ele trata minha mente como uma tela, e projeta seus pensamentos nela (Sass, 1999: 261$)^{5}$.
} 
Pois bem: a relevância de uma heurística da insanidade informada por experiências como aquelas mencionadas acima deriva do fato de que, com base na investigação de situações de colapso da normalidade, ela nos faculta apreender, de maneira muito mais nítida, uma montanha de fatores pressupostos em qualquer interação social "normal"6.

\section{O espelho de Machado.}

\section{Há mesmo um "eu" por trás do uniforme?}

No presente artigo, pretendo concentrar-me sobre uma modalidade específica de "cisão vivida" na esquizofrenia que desponta como particularmente relevante para as preocupações analíticas da teoria social, a saber, aquela entre o indivíduo e seus "papéis", suas "identidades" ou suas "posições de sujeito" na vida societária7. A despeito dos usos teóricos inegavelmente distintos de tais conceitos, todos eles buscam apreender, de um modo ou de outro, um dos principais processos pelos quais condutas individuais se conectam a estruturas sociais, qual seja, aquele em que indivíduos empíricos encarnam "tipos" associados a formas padronizadas de ação: garçom, guarda de trânsito, médica, policial, mulher, homem, mãe, pai, esposa, marido, católico etc. Tradições teóricas diversas acentuaram aspectos distintos de tais performances de papel, como as expectativas normativas embutidas nos papéis, os impulsos libidinais que levam os agentes a investir nos seus desempenhos ou, ainda, as competências cognitivas e práticas sem as quais tais desempenhos não seriam possíveis. O estrutural-funcionalismo de Parsons, por exemplo, concentrou-se sobre as expectativas normativas associadas aos papéis sociais, bem como sobre a internalização de tais expectativas na personalidade via socialização (1991: 138). Segundo a crítica avançada pelas microssociologias interpretativas, no entanto, o autor estadunidense não teria levado suficientemente em consideração o fato de que performances de papel são desempenhos qualificados, isto é, dependentes de competências cognitivas complexas (Cohen, 1996).

É curioso notar que debates a respeito dessas mesmas dimensões da relação entre o "indivíduo-como-sujeito-empírico", de um lado, e o "indivíduo-como-sujeito-social", de outro, aparecem em correntes teóricas distintas. Veja-se o exemplo do diálogo crítico de Stuart Hall (2000: 112) com a teoria althusseriana da "interpelação" do sujeito pela ordem social. Na visão pós-estruturalista de Hall, um exame de como os indivíduos encarnam as identidades ou "posições de sujeito" que ocupam em formações sociais não pode escapar à questão da "identificação". Em outras palavras, não é suficiente apontar para os modos pelos quais a ordem social interpela os indivíduos; urge também reconstruir o caminho psíquico que leva do indivíduo à "posição de sujeito" a ele atribuída em um contexto societário. Por que os agentes
6. Como mostrou a pintura fenomenológica do estrangeiro por Schütz (1979: 80-81; 87-95), o estudo de como uma subjetividade reage a um "mundo da vida" no qual ela não foi socializada possibilita uma intelecção $a$ contrario, por assim dizer, de quão vastos são os domínios de incerteza potencial que aqueles pressupostos partilhados de conhecimento e ação no universo social são voltados a neutralizar. Em termos sociológicos, o componente "esquizo" nas vivências esquizoides e esquizofrênicas refere-se a uma espécie de versão existencial generalizada de tal experiência do "estrangeiro".

7. Para demonstrar de modo mais persuasivo a relevância intelectual de experiências esquizoides e esquizofrênicas para a teoria social, o presente artigo dialoga com abordagens diversas, explorando os pontos em comum entre diferentes ferramentas conceituais voltadas à captura da relação entre os indivíduos empíricos, de um lado, e os indivíduos tal como performativamente definidos por outros e por si mesmos, de outro. Como mostraram as abordagens de 
síntese associadas ao (outrora) "novo movimento teórico" (Alexander 1987), tais quais a praxiologia de Bourdieu (1983: 20) e o estruturacionismo de Giddens (2003 XIV), a teorização substantiva nas ciências sociais frequentemente só é capaz de avançar com base na articulação de ferramentas analíticas oriundas de perspectivas teóricas discrepantes ou mesmo antagônicas entre si. Com base em tal ecletismo metodologicamente disciplinado, portanto distinto da mera justaposição inconsistente de teorias, é possível encontrar interfaces entre noções como "papel social", seja em sua acepção estruturalfuncionalista (Parsons, 1991: 138168), seja em sua acepção sociológicodramatúrgica (Goffman, 1975), "missão social", nas reflexões do Bourdieu tardio (2001: 253-300), e identidade ou "posição de sujeito", em reflexões estruturalistas e pós-estruturalistas (e.g., Hall, 2000: 112) sem descambar, no entanto, para a absurda sugestão de que elas seriam idênticas no seu escopo conceitual.

investem, afinal de contas, sua "libido" nas identidades sociais que desempenham? Nos termos de Hall:

\begin{abstract}
Se uma suturação eficaz do sujeito a uma posição-de-sujeito exige não apenas que o sujeito seja "convocado", mas que o sujeito invista naquela posição, então a suturação tem que ser pensada como uma articulação e não como um processo unilateral. Isso, por sua vez, coloca, com toda a força, a identificação na pauta teórica (Hall, 2000: 112).
\end{abstract}

Uma vez mais, sem que seja preciso descambar para a simples confusão entre diferentes matrizes teóricas, a ideia de que "papéis", "identidades" e "posições de sujeito" são "suturas" - como diz Stuart Hall - ou "cordas atadas" - para usar a clássica expressão que Nietzsche mobilizou em outro contexto - entre indivíduo e sociedade, agência e estrutura, é efetivamente partilhada por teorias as mais diversas. E Hall tem razão em sublinhar que uma análise dessas suturas é levada a uma explicação dos investimentos de tempo, energia, recursos - em suma, de libido no sentido mais geral de "pulsão de vida" - na manutenção das identidades que os indivíduos encarnam em seus contextos sociais de existência. Nas suas versões mais críticas às "ilusões da autoconsciência", várias dessas análises mostraram, de um modo ou de outro, que os investimentos psíquicos e existenciais dos indivíduos em certas de suas identidades sociais são tão importantes que a dissolução de tais identidades levaria à dissolução mesma de qualquer senso nítido e preciso de si. Uma versão alegórica dessa tese já aparecia - é interessante notar - no conto "O espelho: esboço de uma nova teoria da alma humana" de Machado de Assis. Se, por um lado, não há dúvida de que o tom pomposo do subtítulo já brotou de sua pena carregado de ironia, também não há por que ignorar, por outro lado, a real densidade filosófica da narrativa machadiana. A história trata do curioso caso de Jacobina, personagem que, frente ao espelho, só percebia sua própria imagem integral quando estava vestido com sua farda de alferes da guarda nacional. Despido do uniforme prestigioso, Jacobina via seu reflexo tornar-se "disperso, esgaçado, mutilado..." (Assis, 2007: 161). Como sublinharam Antonio Candido (1995: 29) e Augusto Meyer (2008: 54), a experiência de Jacobina diante do espelho pode ser interpretada como alegoria de uma tese sociopsicológica sobre o animal humano: experimentamos pelo menos alguns de nossos papéis e identidades sociais não como meras máscaras externas ao nosso verdadeiro "eu", mas como aspectos indissociáveis do que consideramos nosso ser mais íntimo e "essencial". Nas palavras de Meyer:

Jacobina somos nós. Botamos a farda e representamos...não na vida social apenas, na vida profunda do espírito, que anda qua- 
se sempre fardado. [...] Quem tira a farda, quem tenta ver além da fantasmagoria organizada em seu proveito pela inconsciência vital, sente a vertigem de si mesmo e de tudo, e acaba falando sozinho diante do espelho, como o alferes Jacobina (Meyer, 2008: 54).

O recurso machadiano aos artifícios artísticos do gênero cômico-fantástico serve como modo de transmitir uma verdade sociopsicológica que, na maior parte do tempo, resta escondida para a maioria das pessoas. Um dos aspectos mais impressionantes da literatura sobre vivências do mundo e de si na esquizofrenia é a descoberta de que formas de experiência que julgávamos ser possíveis apenas em um experimentum mentis filosófico ou na literatura fantástica adquirem realidade subjetiva para algumas pessoas. A experiência de ter o próprio eu "disperso, esgaçado, mutilado" pela retirada dos "uniformes" sociais pelos quais nos apresentamos ao mundo é uma dessas vivências angustiosas reais - isto é, vividas como reais - em casos diversos de esquizofrenia.

\section{O exilado existencial}

Como notamos acima, a palavra "esquizofrenia" foi montada pelo psiquiatra suíço Eugen Bleuler lá pela casa de 1911, em uma justaposição dos radicais gregos referentes respectivamente a "cisão" e "mente". A despeito das transformações ulteriores de sentido sofridas por essa categoria - uma das mais polissêmicas e controversas na história da psiquiatria -, o conceito de "esquizofrenia" continua a veicular a intenção bleuleriana inicial de capturar distúrbios ou rupturas no senso vivido de conexão do indivíduo com seu mundo circundante e/ou com sua própria subjetividade. A angustiosa experiência de uma barreira existencial entre a própria subjetividade e o mundo exterior já foi apresentada, nas seções pregressas deste artigo, como característica de diversos casos de esquizofrenia. Bem entendido, experiências de estranhamento do mundo e de si não são apanágio exclusivo da esquizofrenia em suas manifestações mais radicais, mas consistem, em suas versões menos frequentes e/ou intensas, em parte e parcela da experiência humana como tal. Entre a experiência do mundo circundante e da própria subjetividade como realidades absolutamente familiares, em um extremo, e o estranhamento total do mundo e de si, no outro, há todo um continuum de possibilidades intermediárias que combinam graus diversos de segurança e insegurança existencial na experiência de "ser-si-em-um-mundo".

Seja como for, ao diferenciar as fases psicóticas das fases não psicóticas da condição esquizofrênica, Bleuler examinou certas características relativamente duráveis de
8. Nesse sentido, poderíamos falar que um elemento "esquizoide" - ou simplesmente "esquizo" - emerge na experiência humana em quaisquer cenários "normais" de perturbação existencial na conexão segura da subjetividade com o mundo ou da subjetividade consigo mesma (Peters, 2017) - por exemplo, na desorientação ontológica que sentimos quando acordamos repentinamente de um sonho e precisamos, assim, reajustar nosso senso do que é (ir)real ou, ainda, quando em nossa mente pipoca um pensamento cuja bizarrice nos parece completamente estranha a quem "realmente" somos. 
personalidade que pacientes em delírio apresentavam antes de mergulharem na psicose propriamente dita. O psiquiatra suíço chegou à conclusão de que a maioria dos casos de delírio psicótico afligiria indivíduos dotados dos atributos de uma "personalidade esquizoide". Na medida em que a exuberância das manifestações psicóticas é o que costuma ganhar a atenção do senso comum para a esquizofrenia, é importante ressalvar aqui que o inverso não procede: a maior parte das pessoas que se enquadram nesse tipo psíquico não evolui para quadros psicóticos (Sass \& Parnas, 2000). Como acabei de sublinhar, pode-se sustentar que experiências esquizoides, nas quais a subjetividade experimenta algum hiato entre seu "espaço interno" e o mundo - ou entre tal e qual dimensão do seu self-, são parte e parcela da condição humana "normal".

Ao ser observada através de uma lente sociológica, a visão bleuleriana da personalidade esquizoide pode ser considerada como uma espécie de figura invertida das perspectivas teóricas sobre a conduta humana que - como a fenomenologia schutziana da "atitude natural" ou a praxiologia de Pierre Bourdieu - privilegiam a análise de casos de "cumplicidade ontológica" (Bourdieu, 1988: 52) entre as disposições subjetivas do agente e suas circunstâncias sócio-históricas de experiência. Na medida em que um dos produtos da socialização da subjetividade é a internalização de esquemas cognitivos de percepção intersubjetivamente vigentes no próprio cenário socializador, tal cenário não será visto pelo indivíduo socializado como uma ordem social contingente e arbitrária, mas como a própria ordem natural e autoevidente das coisas. Uma vez que as expectativas e competências subjetivas que o animam e capacitam a intervir no mundo social estão harmonizadas com as demandas práticas de seus contextos de ação, o indivíduo experimenta um senso global e difuso, cognitivo e afetivo, mental e corpóreo de estar "em casa no mundo" (Gadamer, 1996: 154), tal qual "um peixe n'água" (Vandenberghe, 2010: 65). Em contraste, o núcleo experiencial de uma relação esquizoide com o mundo é precisamente a ausência dessa sensação difusa de estar à vontade, confortável, seguro ou "em casa" em um ambiente circundante de pessoas, atividades, coisas e símbolos (Jaspers, 1979a: 121).

A sensação de estranheza que a própria subjetividade esquizoide vivencia no seu trato com outros tende frequentemente a ser, por assim dizer, devolvida a ela. 0 próprio Jaspers (1979a) elencou, entre os índices de esquizofrenia que reconhecia em seus pacientes, seu senso intuitivo - inequivocamente experimentado, mas difícil de descrever - de que alguma espécie de abismo experiencial o separava daqueles indivíduos. Em termos mais simplórios, indivíduos que vivenciam um estranhamento em relação ao mundo e aos outros são com frequência classificados como "estranhos", por seu turno, pelas pessoas com quem interagem socialmente 
- incluindo-se aí, a crer em Jaspers, seus próprios psiquiatras. Se tomados como marcos diagnósticos, é claro que atributos psíquicos como "estranheza" ou "excentricidade" já funcionaram de justificativa para todo um conjunto de trágicos abusos cometidos pela psiquiatria. Do ponto de vista sociológico, no entanto, tais características são relevantes a uma interpretação das consequências provocadas pela esquizofrenia no âmbito interacional, as quais tomam a forma, em sua maior parte, do que Erving Goffman (1963: 216) denominou "impropriedades situacionais". Quando especificam o senso de estranheza gerado pelas subjetividades esquizoides com as quais interagem, algumas pessoas qualificam o comportamento das últimas como "artificial", "robótico", "mecânico", "irônico", "desengajado" ou "forçado". Em contraste com o feitio espontâneo da conduta socialmente "normal", o modo de portar-se do sujeito esquizoide pareceria demasiado calculista ou cerebral. Este aspecto de falta de espontaneidade, naturalidade ou autenticidade de suas condutas, tal como ele aparece em sua condução do próprio corpo e em sua (in)expressividade afetiva, viria a lume sobretudo nas suas performances ordinárias de papéis sociais, isto é, nas maneiras pelas quais o indivíduo esquizoide se envolve em "rituais de interação" cotidianos.

\section{As máscaras de Shakespeare; ou o mundo social como teatro}

O valor analítico do conceito de "rituais de interação" foi amplamente evidenciado, é claro, pela microssociologia da ordem interacional elaborada por Goffman ao longo de toda a sua carreira (Goffman, 1963; 1967; 1974; 1975). A vivência partilhada de uma barreira entre a personalidade esquizoide e os agentes presentes nos seus cenários de interação também pode ser entendida - acredito - à luz de outra orientação analítica legada pelo sociólogo canadense: a investigação dos requisitos cênicos ou teatrais da vida social. Goffman (1975: 74-75) foi parcialmente inspirado por Sartre, cuja psicologia do desempenho de papéis sociais como performance teatral é uma das consequências de sua antropologia filosófica existencialista. Grosso modo, o filósofo francês retrata o ser humano como inerentemente angustiado (ou "nauseado") por um "nada" que o habita do interior, identificado por Sartre à radical contingência de uma criatura obrigada a inventar a si própria sem qualquer apoio na natureza das coisas ou em um Deus. A visão sartriana toma de empréstimo a Kierkegaard uma caracterização da angústia como "vertigem da liberdade", experiência em que o ser humano intui sua condição incontornável de inventor de si mesmo. Assoberbado frente à responsabilidade da criação livre de si em face de tantas possibilidades contingentes, o ser humano sofre a tentação de escapar dessa angustiante responsabilidade pela via do que Sartre (1997: 92) chamou de má-fé: o autoengano em que o sujeito tenta conceber a si próprio e a 
se portar como coisa ou "ser em-si". Sartre gostava de escrever em cafés. Assim, precisou somente levantar a cabeça para encontrar no garçom um exemplo que se tornaria famoso.

\footnotetext{
Vejamos esse garçom. Tem gestos vivos e marcados, um tanto precisos demais, um pouco rápido demais, e se inclina com presteza algo excessiva. Sua voz e seus olhos exprimem interesse talvez demasiado solícito pelo pedido do freguês. Afinal volta-se, tentando imitar o rigor inflexível de sabe-se lá que autômato... Sua mímica e sua voz parecem mecanismos, e ele assume a presteza e rapidez inexorável das coisas (Sartre, 1997: 106).
}

9. O mesmo valeria para outras tantas dimensões da interação, como o revezamento normativo entre fala e escuta ("quanto tempo cada um de nós deve falar até que o outro tome a palavra?") ou os rituais de estranhamento polido ou "desatenção civil" (Goffman, 1963: 83) entre estranhos em locais públicos ("sei que devo olhar para o estranho por tempo suficiente para indicar que percebi sua presença, mas não por tempo demasiado a ponto de torná-lo desconfortável com meu interesse por ele, mas quais são os intervalos de tempo que correspondem exatamente a essas exigências?") e assim por diante.
Seja como for, diferentemente do que é sustentado por visões da psicopatologia como mero déficit e incapacidade, várias das dificuldades relacionais vividas por indivíduos esquizoides não derivam da falta de consciência daqueles requisitos teatrais da interação social rotineira, mas, ao contrário, de uma excessiva autoconsciência ou mórbida hiper-reflexividade quanto a eles. Uma das condições psicológicas de possibilidade da competência interacional no mundo social é precisamente o abandono de toda uma série de aspectos da interação ao domínio do que é implicitamente "visto, mas não percebido" (Garfinkel, 1967: 36). Em contraste, imagine um indivíduo que não consegue deixar de trazer ao plano da reflexão explícita todas as dimensões da interação social que abandonamos tranquilamente àquele saber prático, implícito, intuitivo que Goffman (1975: 214) capturou na ideia de "tato": o equilíbrio entre proximidade e distância em relação ao nosso interlocutor, o manejo de nossas posturas corporais, o revezamento entre escuta e fala, o movimento de nossas próprias pálpebras conforme abrimos e fechamos os olhos. Tal como falamos anteriormente em um "ceticismo vivido", há algo como um "goffmanianismo vivido" em alguns casos de experiência esquizofrênica, nos quais os indivíduos são tão atentos e sensíveis aos menores aspectos da interação social que se veem assoberbados, cognitiva e afetivamente, pelas demandas dos encontros sociais mais rotineiros. O caráter "vago" dos requisitos normativos tácitos da interação social mapeados por Goffman também explica por que tais dificuldades acometem frequentemente espíritos "geométricos" (Minkowski, 2002), racionalistas e hiperanalíticos, facilmente ansiosos diante de orientações de conduta insuficientemente precisas. Por exemplo, diante do nosso interlocutor em uma conversação rotineira, sabemos que não devemos estar nem demasiado distantes, a ponto de sugerir que não gostaríamos de travar um verdadeiro contato com ele, nem demasiado próximos, para não invadirmos a privacidade de seu espaço imediato. No mais das vezes, é claro, nosso conhecimento da distância adequada é intuitivamente sentido e ajustado, em vez de formulado como orientação precisa e explícita (por exemplo, "N centímetros") ${ }^{9}$. Como em outras conjugações ambivalentes de "competência" e 
"incompetência" na esquizofrenia, a consciência ampliada do indivíduo esquizoide a respeito dos requisitos implícitos da interação social, "sociologicamente" sagaz à sua maneira, o leva a pagar um preço cognitivo, emocional e prático por sua lucidez. Vejamos.

De uma perspectiva estritamente sociológica, o critério definidor da "normalidade" de uma forma de conduta consiste no ajuste entre as expectativas e capacidades subjetivas do agente, de um lado, e as exigências práticas a ele dirigidas por seu contexto societário, de outro. Eis por que, como evidenciam análises historiográficas e etnológicas da loucura (e.g., Benedict, 1961: 218-240), condutas tomadas como normais em um cenário histórico-cultural seriam consideradas insanas em outros e vice-versa (considere-se, por exemplo, o autoflagelo em público como ritual de expiação religiosa, ocorrência normal na Europa medieval, porém provável signo de loucura em qualquer cidade do Ocidente moderno). O senso de (des)ajuste entre as orientações subjetivas do agente e suas circunstâncias sociais de ação foi tema dileto, como se sabe, das teorias sociopsicológicas pragmatistas (Aboulafia, 1999). Segundo tais teorias, a vivência reiterada da convergência entre o que os agentes esperam de suas situações sociais, de um lado, e o que as situações sociais demandam dos agentes, de outro, leva a uma habituação mental e corpórea, a qual libera energia e "espaço" psíquico para que a consciência reflexiva se concentre sobre outras coisas (por exemplo, refletimos sobre os arcanos da filosofia de Heidegger enquanto abandonamos a tarefa de caminhar, lavar a louça, ensaboar-se no chuveiro ou dirigir um carro a um corpo já bem treinado nessas ações). Aplicada aos requisitos teatrais da interação societária, a tendência humana à habituação tende a lançar para um domínio implícito e infraconsciente o senso que o próprio agente tem quanto à teatralidade de sua conduta. A performance cênica de papéis sociais em encontros ordinários torna-se, nesse sentido, tanto um desempenho habilidoso quanto uma verdade escondida ou, pelo menos, submetida a uma epoché pela maior parte dos atores engajados nos teatros da vida social. Pode ser verdade, o que rezam os versos shakespearianos de "Como gostais": "o mundo inteiro é um palco, e todos os homens e mulheres, apenas atores". Ainda assim, um indivíduo incapaz de banir essa verdade para as margens de sua consciência em sua experiência social ordinária se verá, muito provavelmente, um tanto travado e atrapaIhado na realização de performances que outros abandonam, com tranquilidade e fluência, às propensões habituais de um corpo bem treinado naquele(s) teatro(s). Imagine-se, por exemplo, uma situação de conversa na qual um dos participantes precisa realizar, de modo intencional e reflexivo, os movimentos do corpo e do rosto que a maioria dos agentes ativa de maneira inconsciente e espontânea, como parte de uma linguagem não verbal habitualizada. Já que a reflexividade desse indivíduo está sobrecarregada com tarefas que os outros abandonam calmamente aos 
10. Em princípio, a atenção do indivíduo esquizoide ou esquizofrênico se encontra tomada assim, por muito mais informação do que aquela manejada por seu interlocutor. Para ter uma ideia do que acontece, experimente, por exemplo, prestar atenção explícita aos mínimos movimentos de seu corpo e de seu rosto diante de um interlocutor, a começar pelo abrir e fechar periódico de suas próprias pálpebras, e então veja o que isto faz com sua capacidade de concentração sobre o que está sendo dito. Em um efeito perverso, típico das dinâmicas de estigmatização da loucura, é possível que a dificuldade de apreensão que o indivíduo esquizoide tem do discurso alheio, prejudicada por sua intensa atividade mental ou excesso de reflexão sobre o próprio corpo, seja atribuída por outras pessoas (incluindo os psiquiatras) a um mero déficit cognitivo. seus hábitos corporais, ele não se verá com muita energia psíquica restante para se concentrar no assunto de que fala seu interlocutor ${ }^{10}$.

As perturbações psicológicas e práticas oriundas do "goffmanianismo vivido" na experiência esquizoide podem ser compreendidas - creio eu - mediante uma aproximação aos casos de "estruturalismo vivido" característicos de certas anomalias linguísticas descritas na literatura sobre a esquizofrenia (Sass, 1992: 202). Como é sabido, a linguística estrutural de Saussure (1971) sublinhou que não há qualquer laço ontologicamente necessário entre significantes gráficos e sonoros, de um lado, e os significados aos quais eles se referem, de outro. Ao mesmo tempo, seria impossível participar fluentemente da conversação mais corriqueira se a arbitrariedade ontológica do signo jamais escapasse ao foco primeiro de nossa consciência. Assim como a filósofa cética é obrigada a abraçar a postura filosoficamente leviana da "atitude natural" para operar na vida cotidiana, mesmo o estruturalista mais empedernido só é capaz de conversar "competentemente" caso tome os significantes ali usados, na prática, como veículos imediatos e transparentes de seus significados. Em contraposição, um indivíduo que jamais colocasse entre parênteses sua consciência do caráter socialmente convencional e ontologicamente arbitrário do vínculo entre sons e sentidos teria imensa dificuldade em manter o fluxo do intercurso verbal com outros. De maneira similar, uma postura hiper-reflexiva acerca dos aspectos teatralizados da interação social cotidiana, até mesmo daqueles que a maior parte das pessoas abandona ao seu senso prático (por exemplo, o manejo das próprias posturas corpóreas), termina por imbuir a conduta do indivíduo esquizoide ou esquizofrênico com uma marca de estranheza, artificialidade ou afetação robótica.

Ao avançar na heurística sociológica da teatralidade, pode-se perguntar: o que diferencia a atuação típica do sentimentalismo mais kitsch, de um lado, de uma performance teatral que exprime fidedignamente uma emoção dramática, de outro? Uma resposta epigramática evocaria a diferença entre "atuar mais" e "atuar meIhor": em contraste com a primeira, a segunda performance é teatralmente mais convincente porque melhor esconde seu próprio caráter de representação teatral. Ars est celarem artem (a arte é dissimular a arte), reza o provérbio que também se aplica à apresentação teatral de si na vida social ordinária. Uma historicização dos modos teatralizados de "administração da impressão" investigados por Goffman (1975: 191) faria bem em retornar à complexificação dos padrões de interação capitaneados, no processo de "civilização dos costumes" característico da transição à modernidade, pela "sociedade de corte" (Elias, 1994; 2001). E, com efeito, é em um livro quinhentista de lições para o cortesão escrito por Baldassare Castiglione (1997: 42) que encontramos um conceito que bem captura aquela alquimia ineren- 
te à performance socioteatral bem-sucedida: sprezzatura. Graças a tal operação alquímica do ator competente, o suado esforço dispendido no seu cultivo de uma persona social desaparece na exibição mesma dessa persona, que assume então a aura da mais espontânea naturalidade.

\section{O ator (des)crente de si}

No teatro da existência social cotidiana, a ocultação teatral da teatralidade das próprias performances não resulta, no mais das vezes, de um cálculo consciente pelo qual o ator procura persuadir seu público. A prolongada socialização no desempenho de papéis sociais, ao facultar ao agente refinar suas competências performáticas, acaba por neutralizar - como vimos - sua consciência acerca das diversas dimensões dramatúrgicas que ele mobiliza em suas ações de maneira implícita, tácita, não reflexiva. Como pode atestar qualquer indivíduo (estudante, desportista, instrumentista musical, professor etc.) que já vivenciou uma dificuldade em largar-se ao senso prático ao se apresentar em face de uma audiência, refletir explicitamente sobre uma performance no próprio momento em que se a executa atrapalha um tanto a sua fluência. Não por nada, o cultivo da habilidade performativa não está calcado somente, nem mesmo predominantemente, na memorização explícita de diretrizes de conduta, mas na interiorização mental e corpórea de esquemas de ação que integram componentes em um todo ordenado: uma Gestalt (Fuchs, 2001: 324). Graças à popularidade da Gestalttheorie no âmbito de estudos de percepção, os exemplos de Gestalt que nos vêm mais facilmente à mente remetem aos todos inteligíveis apreendidos por nossas faculdades perceptuais (por exemplo, um rosto humano). No seio de uma psicologia da aquisição de competências, no entanto, o conceito de Gestalt também é aplicável a performances motoras habilidosas, tais como andar de bicicleta, ou mesmo a pé, e dirigir um carro. O que estas ilustrações evidenciam é que os estímulos de uma situação de ação particular ativam, na subjetividade dos agentes, esquemas inteiros de resposta prática, como mostra a conexão entre faculdades cognitivas e motoras nas condutas acima elencadas - por exemplo, a articulação rápida e espontânea entre a interpretação cognitiva de informação perceptual (e.g., o significado do sinal vermelho) e os movimentos intencionais do corpo (e.g., tirar o pé do acelerador e pisar no freio).

Poucas linhas de pensamento utilizaram a noção de esquemas de modo tão fecundo quanto a sociologia disposicional de Bourdieu, cujo conceito de habitus sublinha a operação entrelaçada dos diversos aspectos da subjetividade. No sentido mais geral, o habitus é uma "subjetividade socializada" (Bourdieu \& Wacquant, 1992: 126), um conjunto de disposições mentais e corpóreas (modos de agir, pensar, sentir, perceber, interpretar etc.) adquiridas via socialização e mobilizadas nas práticas 
11. Ao recorrer à analogia com o desempenho de papéis teatrais para tratar da ativação corpórea de "estados de alma", a posição de Bourdieu (2001: 189) está em oposição direta ao modo demasiado intelectualista pelo qual Sartre retrata a performance do "garçom de café", retratável à incapacidade de Sartre em diferenciar sua atitude existencial diante do mundo (contemplativa e reflexiva) daquela dos agentes que ele examina (pragmática, baseada em improvisações tácitas, imersa na "urgência da prática" etc.). Para um exame do diálogo crítico de Bourdieu com Sartre acerca dessa questão, ver Peters (2012: 250-252). pelas quais os agentes reproduzem historicamente seus contextos estruturais de ação. Bourdieu (1988: 16) sublinha que a operação do habitus entrelaça as dimensões cognitiva (eidos), avaliativa (ethos) e corpóreo-afetiva (hexis) da subjetividade. Ao caracterizar o habitus como um conjunto de "esquemas de percepção, avaliação e ação" (Bourdieu, 2009: 30; Peters, 2015: 80-86), Bourdieu quis enfatizar a articulação entre os esquemas cognitivos pelos quais se dá inteligibilidade ao mundo (por exemplo, as ferramentas de classificação que nos levam a interpretar um terno como signo de classe), os esquemas avaliativos pelos quais as entidades percebidas são situadas em uma escala de valor social diferencial (por exemplo, o contraste do terno com as formas de vestuário simbolicamente associadas à pobreza) e, finalmente, os esquemas de ação pelos quais se responde na prática aos estímulos do mundo social (por exemplo, no caso do preconceito de classe, uma atitude corpórea de afastamento, aversão ou repulsa em relação a agentes que carregam índices simbólicos de pobreza). Bourdieu oferece, ademais, um lembrete do caminho de mão dupla na relação entre crença mental e experiência corpórea: o ator desempenha seus papéis sociais com habilidade porque acredita neles, mas também crê neles mais intensamente porque os desempenha com frequência. Graças à imersão na atmosfera de uma situação estruturada para estimular tais ou quais "estados de alma", como o "clima" lúdico de uma festa ou o "clima" solene de uma missa, o agente mobiliza um esquema de resposta global ao seu contexto experiencial - casu quo, os esquemas respectivamente associados a estados de espírito festivos ou reverenciais. Quanto a este papel do corpo situado na indução de estados mentais, é o próprio Bourdieu quem recorre ao exemplo heurístico do teatro em $O$ senso prático (2009: 113).

\footnotetext{
Todas as ordens sociais sistematicamente tiram proveito da disposição do corpo e da linguagem para funcionar como depósitos de pensamentos diferidos, que poderão ser desencadeados à distância e com efeito retardado, pelo simples fato de recolocar o corpo em uma postura global apropriada para evocar os sentimentos e os pensamentos que lhe são associados, em um desses estados indutores do corpo que, como é de conhecimento dos atores, provocam os estados de alma (Bourdieu, 2009: 113) $)^{11}$.
}

Uma vez mais, os atores que creem com vigor na realidade de seus papéis sociais tendem a desempenhá-los habilidosamente, mas o reverso também se aplica: performances reiteradas de um papel social intensificam aquela crença não apenas em um âmbito estritamente cognitivo, mas também visceral e existencial. A intensificação da crença se ancora ainda em todos os suportes sociais estabelecidos para dar a ela a aura de máxima realidade, a começar por atores que acreditam intensamente na realidade dos papéis desempenhados pelo indivíduo e dos seus 
próprios. Como há muito já notaram analistas da religião (e.g., Becker, 2010), uma cosmologia só adquire continuidade histórica quando interiorizada nos corpos dos fiéis através de rituais periódicos e materializada em índices palpáveis de sua presença no mundo, como "préstitos, multidões, trajes cerimoniais" e "dias especiais assinalados nos calendários" (Becker, 2010: 244). Por meio do engajamento do ator em tais práticas afetivamente carregadas, sua trajetória experiencial vai deixando em sua subjetividade "depósitos" (Bourdieu) ou "sedimentos" (Husserl, 1973: 122) sob a forma de disposições a pensar, sentir e agir como no passado12.

Em sua aparição na sociologia disposicional de Bourdieu (2002) e de seu discípulo crítico Bernard Lahire (2002), o conceito de "esquemas" subjetivos trai uma similaridade algo frouxa, mas analiticamente sugestiva, com a noção de "complexos" usada por Bleuler (1969: 323) em seu estudo psiquiátrico sobre o "grupo das esquizofrenias". Como vimos, a junção de radicais indicativos de "cisão" e "mente" já apontava para uma condição que envolvia ruptura de laços entre aspectos "normalmente" integrados da psique. As cisões características da esquizofrenia atacariam - segundo a visão bleuleriana - os vínculos lógicos das ideias umas com as outras (por exemplo, na substituição de associações ideativas ordenadas por cadeias associativas crescentemente incompreensíveis ${ }^{13}$ ), das ideias com suas ressonâncias afetivas (por exemplo, na produção de respostas emocionais socialmente ininteligíveis e inapropriadas, como a risada em meio a uma situação grave) e, finalmente, do sujeito com seu mundo circundante (por exemplo, na fase da esquizofrenia que Bleuler chamou de "autismo", em que o indivíduo, assoberbado pela desorganização da sua personalidade, desiste de se engajar na vida social e como que se isola dentro de sua própria psique) (Bleuler, 1969: 373).

\section{A toupeira de Kafka; \\ ou a cidadela que aprisiona}

No entrecruzamento entre fenomenologia da esquizofrenia e teoria sociológica da ação aqui delineado, poder-se-ia caracterizar tais dissociações esquizofrênicas como formas de "desesquematização", isto é, de perturbações, enfraquecimentos e dissolução dos esquemas disposicionais partilhados em um contexto societário como os complexos globais que distinguem a conduta considerada como apropriada em um jogo entre amigos e em um tribunal (postura corporal, atitude fisionômica, estilo cognitivo e assim por diante). Uma das rupturas disposicionais mais comuns entre sujeitos esquizoides e esquizofrênicos incide sobre os liames entre os estados subjetivos do indivíduo, de um lado, e as performances corporais associadas ao desempenho dramatúrgico de papéis sociais, de outro. Diga-se de passagem - ainda que não possamos elaborar o tema no presente artigo - que o elo psíquico entre o

12. Disposições habituais não são elementos discretos, já notara William James (1961: 5-14), mas conexões firmes entre movimentos do corpo, orientações cognitivas, estados afetivos e um senso visceral de "como é estar" nesta ou naquela situação socialmente tipificada. A tendência de certa ciência social a tratar dos estoques de conhecimento dos atores em termos afetivamente "depurados" torna difícil, por vezes, o reconhecimento daquele senso difuso. Saber o que é uma aula ou uma missa, por exemplo, não envolve apenas o conhecimento dos papéis sociais ali envolvidos (por exemplo, professora, padre) e dos modos de portar-se ali considerados como normativamente apropriados (por exemplo, a prerrogativa da fala autorizada à professora ou ao padre). 0 conhecimento do que são essas situações sociais tipificadas também implica, com frequência, a capacidade de reativar, na memória vivencial, um senso global e difuso de como é estar em uma aula ou em uma missa (Fuchs, 2001: 324).

13. Uma ilustração do que seria provavelmente classificado como "pensamento desorganizado", 
segundo a psiquiatra contemporânea, é dada pela resposta de um paciente solicitado a definir a palavra "pai": "Pais são as pessoas que te criam. Qualquer coisa que te crie pode ser um pai. Pais podem ser qualquer coisa, material, vegetal ou mineral, que te ensinou alguma coisa. Pais seriam o mundo das coisas que estão vivas, que estão lá. Pedras, uma pessoa pode olhar para uma pedra e aprender alguma coisa com ela, então ela seria um pai" (Sass, 1992: 152). indivíduo empírico e seus papéis é somente um entre outros laços característicos do desempenho de práticas sociais ordinárias. Tais laços abarcam, em especial, aquelas conexões duráveis entre orientações mentais e estados corpóreos que Merleau-Ponty (1999) e Bourdieu (2009: 108-132) enfatizaram em suas críticas a concepções dualistas da relação entre mente e corpo na filosofia e na teoria social.

Se Merleau-Ponty e Bourdieu tinham razão em retratar a visão "cartesiana" da relação mente/corpo como largamente irrealista no que toca à maior parcela da agência humana, faltou a eles sublinhar que, em alguns casos de esquizofrenia, o dualismo cartesiano deixa de ser uma ficção filosófica para se tornar uma vivência existencial efetiva. Nesses casos esquizofrênicos de "cartesianismo vivido", a autoidentificação corpórea vai dando lugar a uma percepção do corpo como mais um objeto em meio a outros objetos externos que aparecem à consciência "pura". Em vez de instrumento fundamental de ação e veículo básico da imersão do indivíduo no mundo, o corpo é percebido como entidade exterior com a qual ele não mais se identifica. No dualismo existencial vivido pelo "sujeito desincorporado", para usar a expressão de Ronald Laing, "o corpo é sentido mais como um objeto entre outros objetos no mundo do que como o núcleo da própria existência do indivíduo" (Laing, 1990: 69). Em alguns casos, o "goffmanianismo vivido" que encontramos anteriormente se sobrepõe a tal "cartesianismo vivido", de modo tal que a dissolução da identificação psíquica do indivíduo com seus papéis sociais é experimentada como dissociação radical da consciência em relação às performances corporais. O sujeito-consciência se experimenta distante do corpo-papel. Como o mundo societário continua a exigir de tais indivíduos que desempenhem seus papéis, suas performances são vivenciadas por eles como rituais mecânicos, destituídos de significado afetivo ou envolvimento genuíno.

Tal divórcio do sujeito em relação ao corpo priva o sujeito desincorporado da participação direta em qualquer aspecto da vida do mundo, a qual é mediada exclusivamente através das percepções, sentimentos e movimentos do corpo (expressões, gestos, palavras, ações etc.). O sujeito desincorporado, como um observador de tudo o que o corpo faz, não se engaja em nada diretamente. Suas funções vêm a ser a observação, o controle e a crítica vis-à-vis o que o corpo está experimentando e fazendo, bem como aquelas operações a que normalmente nos referimos como puramente "mentais" (Laing, 1990: 69).

Laing dá uma ilustração dessas trajetórias psíquicas de "desincorporação" com o caso de um de seus pacientes, um rapaz de 18 anos chamado David, cujo desengajamento em relação às performances públicas de papéis sociais emergira como um artifício psíquico defensivo para lidar com sensações assoberbantes de exposição e 
vulnerabilidade aos juízos e olhares de outras pessoas (Laing, 1990: 71). Ademais, a história de David exemplifica um temor à perda do próprio "eu" em interações sociais que marca diversos outros casos de esquizofrenia, nos quais o encontro das subjetividades de ego e alter está a um passo de ser vivido como insuportável. Vejamos.

Como salientou George Herbert Mead, uma das faculdades centrais à participação competente na existência social consiste em saber, pelo menos para todos os propósitos práticos, "colocar-se no lugar do outro". Se tal capacidade é aprendida com algum sofrimento nas primeiras etapas do desenvolvimento psíquico, ela termina por ser interiorizada de maneira tão sólida que podemos ativá-la cotidianamente, de modo tácito e espontâneo, em nossos encontros sociais. É o que fazemos quando cumprimentamos uma pessoa com um aceno ou quando, ao ouvirmos a notícia do falecimento do melhor amigo de um conhecido nosso, inferimos prontamente que tal acontecimento é doloroso para ele. Ao mesmo tempo, igualmente sólido e espontâneo é meu senso implícito de que, a despeito desse exercício de transposição imaginativa para a subjetividade do outro, continuo sendo eu mesmo. Graças a uma empatia espontânea, posso compreender imediatamente, por exemplo, por que um indivíduo recém-atropelado está gemendo de dor, mas sem abandonar meu senso seguro de que não sou eu quem está gemendo de dor. Fuchs (2002) chama este senso de si que subjaz ao contato intersubjetivo de uma "metaperspectiva", enraizada na própria corporeidade, em função da qual meu transporte empático para a subjetividade de alter não ameaça meu senso de autoidentificação. Em algumas experiências esquizofrênicas, é esta ambiguidade inerente à comunicação intersubjetiva que sofre o risco de colapso, levando o indivíduo a aterrorizar-se com a possibilidade de desaparecer pelo contato com o outro - seja "perdendo-se" para sempre na subjetividade de alter ao transportar-se imaginativamente para ela, seja pela "invasão" da própria psique pelos outros que procuram acessá-la por um caminho empático ${ }^{14}$.

No caso de David, sua sensação de vulnerabilidade à mirada julgadora de outros era tão difícil de suportar que ele decidiu assumir uma diferenciação rígida entre as "máscaras de papel" que tinha de vestir em interações sociais, de um lado, e o seu "eu" autêntico seguramente alojado por trás de seus escudos-máscara, de outro. Segundo seu projeto originário, seu verdadeiro "eu" se protegeria, assim, dos perigos de ter a própria existência invadida, violentada ou extinta pelos olhares e juízes alheios. A contraparte do compromisso de David em resguardar seu "eu" real da exposição a outras pessoas consistia em uma estilização teatral da própria conduta que chegava, para observadores externos, ao ponto da caricatura: ele costumava usar uma capa sobre os seus ombros e braços, andava com uma bengala,

\footnotetext{
14. É à luz dessas experiências de ameaça de si por alter que devemos entender afirmações de pacientes que poderiam, de outro modo, soar incompreensíveis, tais como "quando olho para alguém, minha própria personalidade está em perigo" ou "a consciência dos outros se intromete em mim e deixa o meu eu desaparecer" (Fuchs, 2002: 11).
} 
15. A

"personalidade" teatralmente mantida por David diante dos outros era múltipla, comportando um conjunto de diferentes personæ às quais ele se referia na terceira pessoa. Sobre o adolescente desbocado que ele teria representado aos quinze anos, por exemplo, David afirmou a Laing que "ele tinha uma língua ferina" - não apenas utilizando a terceira pessoa do singular, mas o pronome anglófono designativo de entidades inanimadas ou, pelo menos, não humanas: "it had a nasty tongue" (Laing 1990: 72). À maneira do performer que troca de máscaras teatrais segundo considerações instrumentais, David resolvera, então, assumir uma persona mais agradável. falava amplamente por meio de citações e, de maneira geral, tinha um modo de se exprimir e de se portar que parecia inteiramente artificial aos olhos dos outros (Laing, 1990: 70). Ao longo de toda a sua vida, David tinha simplesmente tomado por autoevidente uma diferença abissal entre seu "eu", de um lado, e o que ele chamava de sua "personalidade", de outro. O jovem também tinha por certo que a relação por ele experimentada entre sua autoconcepção íntima (seu "eu" interior e autêntico) e suas condutas diante dos demais indivíduos (a "personalidade" fabricada e controlada sob medida para os outros) era vivenciada, de maneira idêntica, por todas as outras pessoas ${ }^{15}$.

O ideal que guiava sua conduta correspondia, por assim dizer, à versão mais extrema das leituras "cínicas" do Goffman de A representação do eu na vida cotidiana: a figura consciente nos bastidores que exerce um domínio instrumental absoluto sobre suas performances exteriores de papel. O contraponto dessa vontade de controle absoluto de cada detalhe da própria performance externa diante dos outros era - diz Laing - o terror de David quanto à possibilidade de ser "espontâneo", isto é, de comportar-se de uma maneira que escapasse ao seu domínio consciente. Na medida em que eram efeitos não mediados das condutas de outros sobre ele próprio, quaisquer respostas espontâneas significavam estar à mercê desses mesmos outros. Em uma triste ironia, contudo, David foi capturado em uma dinâmica psíquica análoga àquela do famoso conto de Kafka sobre certo animal aparentado a uma toupeira: as defesas psíquicas que o sujeito erige para se abrigar dos possíveis assaltos do mundo externo são as mesmas que o isolam e o aprisionam. Suas condutas em cenários de interação pública são mais e mais experimentadas como dissociadas do verdadeiro self que se oculta atrás de máscaras performativas. Ao olhar desse verdadeiro "eu", tais desempenhos públicos de papel adquirem um sabor de vazio e futilidade ou mesmo de desprezo e ódio. O muro existencial que o indivíduo havia interposto entre si mesmo e o mundo, para abrigá-lo de ameaças provenientes do exterior, é o mesmo que bloqueia o estabelecimento do que Minkowski (2002: 106) chamou de "contato vital com a realidade".

Uma conexão de mão dupla - tal como aquela entre crença e performance que notamos acima no exemplo da experiência religiosa - está em jogo na compreensão desse conceito minkowskiano. Se um ânimo vital é o que impulsiona nossos engajamentos cognitivos e afetivos, mentais e corpóreos, intelectuais e práticos com o mundo das coisas e das outras pessoas, tais engajamentos são, por sua feita, cruciais à manutenção regenerativa de nosso ânimo vital. Uma subjetividade radicalmente desconectada com o mundo se vê destituída da oportunidade de ser psicologicamente enriquecida pelo contato com o real e de desenvolver-se pelo exercício dos seus poderes de agência em face das oportunidades e dos limites, das aberturas e 
resistências que a realidade Ihe impõe. Diante da interrupção desse contato, aquele senso de futilidade e vazio que há muito infectara suas performances públicas de papel passa a fustigar também aquele "eu" interno que havia se retirado de uma vida partilhada com outros. Não apenas sua proteção diante do mundo é paga na moeda de uma sensação de aprisionamento e impotência, mas a atmosfera de irrealidade antes circunscrita aos desempenhos de suas personæ públicas passa a invadir, afinal, a cidadela outrora tão bem guardada. O senso consciente nítido da própria identidade e da solidez da própria existência desaparece, sem que a consciência como tal pare de funcionar. Finalmente, nas palavras de James (outro dos pacientes de Laing), o sujeito vem a vivenciar a si próprio como "apenas um vácuo" (Laing, 1990: 75), esvaziado de interioridade: "sou apenas uma resposta a outras pessoas. Não tenho qualquer identidade própria" (Laing, 1990: 47).

\section{Conclusão:}

a teoria vivida (como esquizofrenia)

Ao recorrer a instrumentos analíticos da sociologia para dar inteligibilidade a experiências "esquizoides" e "esquizofrênicas", o presente artigo esteve menos interessado na (in)correção dessas categorias psiquiátricas do que em oferecer um retrato psicologicamente fidedigno daquelas experiências. Se tivéssemos de esperar a resolução dos debates sobre a validade de rótulos psiquiátricos como "esquizofrenia" para poder avançar na compreensão da "esquizofrenia" como experiência vivida, estaríamos esperando até agora. Conquanto o debate sobre a justeza analítica e ético-política dos rótulos psiquiátricos seja fundamental, também fundamental é a compreensão sociopsicológica das experiências às quais aqueles rótulos aludem (bem ou mal). Dado que o que está em mira é uma pintura substantiva de certas modalidades de vivência humana, também é justificável - acredito - recorrer a um ecletismo pragmático no emprego de ferramentas analíticas. Já que o desiderato do artigo não é a síntese teórica per se, mas o entendimento de fenômenos sociopsicológicos substantivos, aquelas ferramentas podem proceder de perspectivas que são, sob outros aspectos, distintas ou mesmo antagônicas entre si - por exemplo, a microssociologia dramatúrgica do jovem Goffman e a teoria do habitus de Bourdieu.

A relação entre teoria social e fenomenologia da vivência esquizo também pode ser pensada segundo um vai e vem heurístico: se teorias que pensam a vida social a partir da metáfora dramatúrgica auxiliam na compreensão de vivências esquizoides e esquizofrênicas, experiências como aquelas de David e James, analisadas por Laing em $O$ eu dividido, também são relevantes para o exame crítico da microssociologia goffmaniana. No seu clássico Depois da virtude, o tomista extemporâneo Alaisdair Maclntyre (2007: 32) ataca a concepção dramatúrgica da subjetividade 
16. Goffman (1967:

3) condensou seu radical situacionismo teórico-metodológico em uma formulação (androcêntrica) famosa, segundo a qual o foco de sua análise não se voltava a "homens e seus momentos", mas a "momentos e seus homens". Menos conhecida, porém mais relevante para os nossos propósitos, é a redefinição de self que ele oferece naquela que é provavelmente sua obra mais ambiciosa do ponto de vista teórico: Frame analysis (1974). Nesse livro da maturidade, Goffman sustenta que "o self não é uma entidade semiescondida por trás dos eventos", mas "uma fórmula mutável para o manejo de si próprio" em tais eventos (Goffman, 1974: 573) delineada por Goffman na sua obra de estreia, acusando o autor canadense de diluir o self em um conjunto de papéis. Na leitura de Maclntyre, a ideia goffmaniana de que não haveria um self substancial por trás de suas performances ordinárias de papel seria o antípoda da crítica de Sartre à "má-fé", que espinafra justamente o pressuposto de que os indivíduos seriam os papéis sociais que desempenham (por exemplo, o garçom de café). Mesmo assim, prossegue o filósofo britânico, Goffman e Sartre convergiriam afinal na tese de que o self é uma espécie de consciência vazia operando por trás de seus desempenhos de papel. Na concepção goffmaniana, o próprio postulado de que os atores colocam diferentes máscaras performáticas de acordo com os contextos sociais distintos em que operam pressupõe, no mínimo, um "eu" que governa esse vestir e retirar das máscaras conforme as demandas cênicas de seus cenários de interação. Na visão existencialista de Sartre, por sua vez, a ideia de que somos "nada além de um papel" é reputada como válida, não no sentido de que "somos nossos papéis", mas, ao contrário, de que somos esse "nada" consciente que é somente o que faz livremente de si mesmo, escolhendo o que ser em meio a uma série de possibilidades contingentes.

Como é sabido, Goffman (1974: 573) abandonaria, em larga medida, a perspectiva dramatúrgica em suas obras posteriores a The presentation of the self in everyday life. A evolução teórica de sua concepção do self, no entanto, longe de atender à demanda de Maclntyre por uma noção robustecida de subjetividade, não envolveu imbuir de mais substância, realidade, solidez e estabilidade o self que se engaja em interações sociais. Bem ao contrário, Goffman mergulhou mais e mais em um situacionismo radical que perturbou qualquer distinção cerrada entre as máscaras performativas que os atores vestem em contextos sociais diversos, de um lado, e um cínico self interior escondido por trás dos disfarces que veste, de outro ${ }^{16}$. $\mathrm{Na}$ medida em que sua sensibilidade etnográfica à variedade da vida social tinha primazia sobre sua faceta de teórico sistemático, o sociólogo canadense continuou a reconhecer - é claro - que a distinção seria aplicável a certos contextos de ação por exemplo, no caso do empregado que, no período de trabalho, veste a máscara da disposição e da boa vontade diante de um chefe que ele intimamente despreza. A máscara teatral do "empregado disponível e bem-humorado" pode ser ativada e desativada, de maneira mais ou menos instrumental e calculada, conforme o indivíduo se ache dentro ou fora do "palco" relevante. O que dizer, contudo, de papéis mais intimamente atados à autoidentidade desse mesmo sujeito como, digamos, "pai", "marido" ou "católico"?

Encontramos novamente a alegoria machadiana sobre os espíritos fardados e os uniformes do "eu", alguns dos quais se mostram existencialmente tão importantes que, despido deles, o sujeito se despe também de pedaços inteiros de sua autoiden- 
tidade mais íntima e, ao seu ver, essencial. Certas máscaras que vestimos em nosso trânsito experiencial cotidiano pelo mundo social estão, para recorrer à imagem de outro gênio lusófono (Pessoa, 1997: 187), "pegadas", pregadas ou grudadas em nossa face. Quando arrancadas, tais máscaras arrancam com elas pedaços do rosto de quem as veste. Precisamente devido à sua rudeza, a imagem serve de lembrete do quão doloroso pode ser o processo, o qual deixa no seu rastro um indivíduo forçado a carregar - ou, em casos mais esperançosos, a reconstruir - um "eu" mutilado ${ }^{17}$.

E o que ocorre com os indivíduos invadidos pela consciência contínua e intensa da precariedade ontológica de todas as máscaras teatrais e, afinal, da própria criatura consciente que acreditava existir por trás delas? Tal consciência não é apanágio exclusivo de intérpretes de Goffman e Sartre, os quais podem acalentar tais questionamentos ontológicos em um âmbito estritamente intelectual, abandonando-os nas rotinas experienciais da vida cotidiana. Como acontece com a dúvida radical quanto à realidade do mundo material e das outras subjetividades, há uma diferença crucial entre sustentar tais preocupações como exercício cognitivo, de um lado, e levá-las visceralmente a sério na existência cotidiana, de outro. Para alguns indivíduos, o caráter radicalmente problemático da própria existência não se impõe como especulação escolástica, mas como experiência existencial efetiva.

\footnotetext{
Há vezes em que me sinto como um contínuo de "issos", apenas partículas, sem identidade, com nada substancial dentro... [...] Eu me dissolvo em nada, um ser sem face tornando-se partículas, moléculas, átomos e, finalmente, ar. Quem eu sou torna-se menor e menor até que mesmo a minha consciência se esfacele no universo (Glass, 1989: 29-33).
}

Restringir a reflexão sobre estas experiências aos estudos da esquizofrenia, mesmo que em uma chave interdisciplinar, continua a ser uma lamentável limitação analítica. Vivências assim tão peculiares de si e do mundo não deveriam deixar indiferentes - creio eu - quaisquer estudiosos dos múltiplos modos do estar-no-mundo humano.

\section{Referências}

ABOULAFIA, M. A (neo)American in Paris: Bourdieu, mead, and pragmatism. In: SHUSTERMAN, R. Bourdieu: a critical reader. Oxford (UK): Blackwell, 1999.

ALEXANDER, J. O novo movimento teórico. Revista Brasileira de Ciências Sociais, n. 2, 1987.

\author{
17. Na sua \\ clássica análise do \\ manicômio como \\ "instituição total", \\ o próprio Goffman \\ (1996) ofereceu uma \\ contundente análise \\ sociopsicológica \\ da mutilação \\ institucional do \\ "eu" de indivíduos \\ destituídos de um \\ certificado social de \\ sanidade, bem como \\ das estratégias pelas \\ quais tais indivíduos \\ procuravam, ainda \\ assim, preservar- \\ se nas condições \\ adversas em que se \\ encontravam.
}


ASSIS, M. de. O espelho: esboço de uma nova teoria da alma humana. In: GLEDSON, J. (Org.). 50 contos de Machado de Assis, p. 154-162. São Paulo: Companhia das Letras, 2007.

BECKER, E. A negação da morte. São Paulo: Record, 2010.

BENEDICT, R. Patterns of culture. London: Routledge, 1961.

BLEULER, E. Dementia praecox or the group of schizophrenias. New York: International Universities Press, 1969.

BOURDIEU, P. O senso prático. Petrópolis: Vozes, 2009.

— Meditações pascalianas. Rio de Janeiro: Bertrand Brasil, 2001.

— Lições da aula. São Paulo: Ática, 1988.

. Questões de Sociologia. Rio de Janeiro: Marco Zero, 1983.

BOURDIEU; P.; WACQUANT, L. An invitation to a reflexive sociology. Chicago (IL): University of Chicago Press, 1992.

CANDIDO, A. Esquema de Machado de Assis. In CANDIDO, A.: Vários escritos. São Paulo: Duas Cidades, 1995.

CASTIgliONE, B. O livro do cortesão. São Paulo: Martins Fontes, 1997.

COHEN, I. Theories of action and praxis. In: Turner, B. (Org.). The blackwell companion to social theory. Oxford (UK): Blackwell, 1996.

ELIAS, N. A sociedade de corte. Rio de Janeiro: Jorge Zahar, 2001.

— . O processo civilizador (2 v.). Rio de Janeiro: Jorge Zahar, 1994.

FUCHS, T. The challenge of neuroscience: psychiatry and phenomenology today. Psychopathology, v. 35, p. 319-326, 2002.

The tacit dimension. Philosophy, Psychology \& Psychiatry, v. 8, n. 4, p.323-326, 2001.

GADAMER, H. G. The enigma of health. Stanford (CA): Stanford University Press, 1996.

GARFINKEL, H. Studies in ethnomethodology. New Jersey (NJ): Prentice-Hall, 1967.

GIDDENS, A. A constituição da sociedade. São Paulo: Martins Fontes, 2003.

. As consequências da modernidade. São Paulo: Unesp, 2001. 
ـ Sociology: a brief but critical introduction. London: Macmillan, 1986.

GLASS, J. Private terror/Public life. Ithaca (NY): Cornel University Press, 1989.

GOFFMAN, E. Manicômios, prisões e conventos. São Paulo: Perspectiva, 1996.

A representação do eu na vida cotidiana. Petrópolis: Vozes, 1975.

- Frame analysis: an essay on the organization of experience. New York: Harper and Row, 1974.

- Interaction ritual: essays on face-to-face behavior. New York: Pantheon, 1967.

. Behavior in public places. New York: Free Press, 1963.

HALL, S. Quem precisa da identidade? In: SILVA, T. T.(Org.). Identidade e diferença. Petrópolis: Vozes, 2000.

HUSSERL, E. Experience and judgment. Evanston (IL): NorthWestern University Press, 1973.

JAMES, W. Psychology: the briefer course. New York: Harper and Row, 1961.

JASPERS, K. Psicopatologia geral (v. 1). Rio de Janeiro; São Paulo: Atheneu, 1979a.

—_. Psicopatologia geral (v. 2). Rio de Janeiro; São Paulo: Atheneu, 1979 b.

KURASAWA, F. The ethnological imagination. Minneapolis (MN): University of Minnesota Press, 2004.

LAHIRE, B. O homem plural. Petrópolis: Vozes, 2002.

LAING, R. The divided self. Harmondsworth (UK): Penguin, 1990 [1960].

MACINTYRE, A. After virtue: a study in moral theory. Notre Dame (IN): Notre Dame University, 2007.

MERLEAU-PONTY, M. Fenomenologia da percepção. São Paulo: Martins Fontes, 1999.

— . . o visível e o invisível. São Paulo: Perspectiva, 1971.

MEYER, A. Machado de Assis, 1935-1958. Rio de Janeiro: José Olympio; Academia Brasileira de Letras, 2008.

MINKOWSKI, E. La schizophrénie. Paris: Petite Bibliothèque Payot, 2002. 
MINKOWSKI, E. Findings in a case of schizophrenic depression. In: MAY, R.; ANGEL, E. ELLENBERGER, H. (Orgs.). Existence: a new dimension in psychiatry and psychology. New York: Basic Books, 1958.

MORGAN, A. Schizophrenia, reification and deadened life. History of the human sciences, v. 23, n. 5, p.176-193, 2010.

PARSONS, T. The social system. London: Routledge, 1991.

PESSOA, F. O guardador de rebanhos e outros poemas. São Paulo: Cultrix, 1997.

PETERS, G. A ordem social como problema psíquico: do existencialismo sociológico à epistemologia insana. São Paulo: Annablume, 2017.

. Percursos na teoria das práticas sociais: Anthony Giddens e Pierre Bourdieu. São Paulo: Anablume, 2015.

. O social entre o céu e o inferno: a antropologia filosófica de Pierre Bourdieu. Tempo Social, v. 24, n. 1, p. 229-261, 2012.

PINTO, L. Pierre Bourdieu e a teoria do mundo social. São Paulo: Editora FGV, 2000.

SASS, L. Analyzing and deconstructing psychopathology. Theory \& Psychology, v. 9, n. 2, p. 257-268, 1999.

_. Madness and modernism. New York: Basic Books, 1992.

SASS, L.; PARNAS, J. Self, solipsism, and schizophrenic delusions. Philosophy, Psychiatry, \& Psychology, v. 8, n. 2-3, p. 101-120, 2001.

SARTRE, J.-P. O ser e o nada. Petrópolis: Vozes, 1997.

SAUSSURE, F. de. Curso de linguística geral. Lisboa: Publicações Dom Quixote, 1971.

SCHÜTZ, A. Fenomenologia e relações sociais. Rio de Janeiro: Zahar, 1979.

SILVA, L. A. M.; LEITE, M. P. Violência, crime e polícia: o que os favelados dizem quando falam desses temas? In: Silva, L. A. M. (Org.). Vida sob cerco. Rio de Janeiro: Nova Fronteira, 2008.

TAUSK, V. On the origin of the "influencing machine" in schizophrenia. The Journal of Psychotherapy Practice and Research, v. 1, n. 2, p. 185-206, 1992.

VANDENBERGHE, F. Teoria social realista. Belo Horizonte: Editora UFMG, 2010. 